\title{
Community forestry in Nepal: a model of common property resource management
}

\begin{abstract}
K. P. Acharya ${ }^{1}$
The management of common forest land as community forest in Nepal is in practice since 1978. Studies showing the linkages between community forestry and common property resource are scanty in the country. This article discusses characteristics of common property resources and the principles and practices of community forestry in Nepal which is an example of common property resource management between Government agencies and users (co-managers). Forest User Groups (FUGs ) are the institutions responsible to manage the common property.
\end{abstract}

Keywords: Community forestry, common property, use rights, FUGs

ibbs and Bromely (1989) defined property as the $\checkmark$ result of a secure claim to a resource or the services that resource provides. It is not an object rather it is a social relation that defines the property holder with respect to something of value (the benefit stream) against all others. Property is as a social institution and not to any inherent natural or physical qualities of the resource (Bromely 1992; McKean and Ostrom 1995). Four types of property are recognised namely private property, state property, common property, and nonproperty (Bromely 1992; Fenny et al. 1990; Ciriancy-Wantrup and Bishop 1975). The essence of property is exclusion of non-owners. The primary difference among first three property regimes is the decision-making process whereby rules of access and use are set. With open access resources (nonproperty), there is no owner and thus no rights of use or duties of maintenance. Therefore, without defined ownership there can be no rights of exclusion, hence, any one may harvest the benefits of open access resources.

Berkes and Farvar (1989) identified two important characteristics of common property as being exclusion and substractability. They have provided idealised types of property rights relevant to Common Property Resource (CPR) as:

1. Open-access: Free for all; resource use rights are neither exclusive nor transferable; these rights are owned in common but are open access to every one (and therefore property to no one).

2. State property: Ownership and management control is held by the nation, state or crown; public resources to which use rights and access rights have not been specified.

3. property: Use-rights for the resources are controlled by an identifiable group and are not privately owned or managed by governments; there exist rules concerning who may use the resource, who is excluded from using the resource, and how the resource should be used; community based resource management system: common property.

\section{Forest of Nepal as CPR}

Any management of natural resources needs the establishment of property rights (Cox 1992). This is more important in the case of CPR because the management of commons without property rights may become "the tragedy of the commons". According to Karki et al (1994) use rights in most of the forests of Nepal are ill-defined and are being managed as open access property regimes; a situation comparable to what Flardin (1968) called 'the tragedy of the commons'. Large scale deforestation in the past was largely due to everchanging and ill- defined property rights, flawed Government policies and a lack of proper management. Realising this, community forestry (CF) aims to establish the property rights of users over the resources which were either in the state of open access or are managed by local people in the form of de facto property rights situation so that all users (owners) are made co-partners in terms of use-rights. In this connection, Jackson and Ingles (1995) have rightly defined this situation as 'Community Forestry refers to the situation where forests are controlled and managed as common property by groups of rural people who agree to use them to support their farms and households

\section{The Forestry Legislation}

Presently, the Forest Act (1993) and the Forest Regulations (1995) are governing the functioning of

\footnotetext{
${ }^{1}$ Assistant Research Officer, Department of Forest Research and Survey, Kathmandu, Nepal
} 


\section{Acharya}

CF in Nepal. The act defines the main policies and the regulations at operational level. According to these act and regulations, the land managed under CF belongs to the state and the land use rights and forests are owned and managed by the users (HMG 1995a). Important characteristics of formal CF legislation are:

- Land ownership remains with the state, but the land use rights along with the forest resources except wildlife products, soils, sands, etc. belong to FUGs.

- Each member of the FUG is a co-owner and has equal rights over the resources, and 'outsiders' are denied access.

- $\quad$ FUGs will not be affected by political boundaries

- State acts as a facilitator by providing technical supports and advise to users.

\section{Field planning process}

The CF field planning process starts formally with the identification of co-owners of the resource through a procedure similar to Participatory Rural Appraisal (PRA). The community is then organised as a FUG and the District Forest Office (DFO) issues a certificate of recognition to the FUG. Through the series of meetings and discussions among the users the followings arrangements are made by consensus of the users:

- Identification of users and recognition of mutual userights

- Preparation of a constitution describing the conditions for collective action

- Formulation of operational rules describing the terms and conditions for managing resources (An operational plan)

Having done the above procedures, the forest is then formally handed over to the FUG. Review and revision of the OP could be done as and when needed (HMG 1995 b). The existing policy and practice are directed to the hand-over of national forests to identified users. Present legal documents recognise local peoples' rights and responsibilities over the resource formally. Use rights and land ownership of the forest is allocated to the local people and support/advice is provided to them in order to protect, manage and use their forests (Tiwari 1996). This is how the community forest becomes, in a real sense, a common property. These are resources with an identifiable user group; they have finite, subtractive benefits and are potentially subjected to degradation when used beyond sustainable yield limits. Furthermore, community forests are rarely effectively divisible. Moreover,
Banko Janakari, Vol. 9. No. 2

effective collective actions are shown by users when they realise that the forest resource is their "own" property.

\section{Emergence of common property resource institutions}

The emergence of forestry for rural development in the 1970 's challenged the timber-bias profit-oriented industrial forestry and stressed the importance of the participation of the rural people in forestry and the formation of a social organisation capable of sustainable forest management (Wiersum 1989). These social organisations are the non-government local institutions known as Common Property Resource Institutions (CPRIs). Ostrom (1992) defined an institution as "the set of rules actually used (the working rules or rules in use) by a set of individuals to organise repetitive activities that produce outcomes affecting those individuals and potentially affecting others" It was further noted that the development literature defines institutions in three ways (Ostrom 1992);

- As a specific organisation in a particular country,

- As established human relationships in a society, and

- As roles that individuals use to order specific relationships with one another.

Such institutions are capable of functioning independently as a viable alternative to Government organisations for the management of forest resource in varoius circumstances, (e. g. self-emerging indigenous forest management systems; Fisher 1990, externally-sponsored groups such as FUGs formed under CF in Nepal; e. g. Hobley 1996; Karki et al

1994).

FUGs as

common property resource institutions

Forests in the hills of Nepal provide many goods and services to the livlihoods of rural people. Forests, being renewable natural resources should be regarded as capable of sustaining people and being sustained. Flowever, the potential depends on many factors including institutional arrangements and the technical environment. Who controls and how the techniques are applied refers to the institutional arrangements. Tools and knowledge explaining the use of resources refers to the technical environment. For efficient and sustainable functioning of CPR both institutions and technology must complement each other. In the absence of effective institutions resources are degraded and destroyed (Gibbs and Bromely 1992). 


\section{Search for appropriate institutions in community forestry}

Earlier, the local political unit (the Panchayat) was assigned as the institution for forest management. Since it was politcally oriented, was unable to represent the real users. Furthermore, only a limited area could be handed over to such committees. Studies have shown that political units like panchayats were unable to enforce any regulations about CPRs, rather they played decisive roles in converting CPRs into open access (Jodha 1989; Bromley and Cernea 1989). Initially, the panchayat was considered to be an appropriate organisational unit however, it was found that forests were controlled at a lower operating level than the panchayat. The panchayat being a bigger, social and political unit consensus could not be reached regarding management of the forest and distribution of benefits. FUGs at sub-village level with unrestricted administrative boundaries are now recognised as the optimum functional institutions for implementing $\mathrm{CF}$ (Hobley 1996)

The CF policy along with CF legislation has been continuously reformed over time. FUGs emerged as an alternative type of group which is more cohesive and purposeful than the Panchayat. The present policy and legislation recognise FUGs as the appropriate local leve institutions to establish the partnership with the state. FUGs are empowered through legislation and are responsible for forest management. FUGs are institutions at the grass roots level and are viewed as the main mechanisms through which all CF activities will be conducted. The possibility of law enforcement and mutua control is higher in smaller groups like FUGs which helps reduce the potential problem of free-riders in CPR management (Karki et al 1994).

\section{Decision making arrangements}

In the present system, control of forest rests with FUGs. The assembly of a FUG is supreme in making all decisions. Assemblies prepare constitution and OP, define and recognise use rights, decide all kinds of rules, and make forest management decisions including protection, harvesting, benefit sharing, and mobilisation of FUG funds for community development works. The assembly elects a FUC for the execution of FUGs decisions and to conduct day to day work. However, development of an appropriate mechanism to aviod dominance of rural elite and active participation of women and disadvantage group will only in real sense can empower local people in the decision making process.

\section{Conclusion}

The importance of the transfer of property rights from state to forest users was realised after large scale deforestation in the past. This compelled the Government to reallocate use rights to forest user groups. Initial policy and legislation have gone under several changes since it was officially adopted in 1978.

The formal establishment of a FUG with identified forest area provides the base for institutional development. This partnership accepts mutually recognised use-rights among the users, though land ownership remaining with the state. Each member of the FUG has equal rights over the resources and making all kinds of decisions. In future, it is expected that $\mathrm{CF}$ can demonstrate an excellent example of co-management of common property resource in the forestry sector. However, for it's successful functioning, benefit sharing mechanism must involve rural poor and women. Moreover, sustainable management of forest of Nepal can be assured only when community forestry management activities meet the criteria and indicators for the sustainable management of forests.

\section{References}

Berkes, F. and Farvar, T. 1989. Introduction and overview. In Berkes, F. (ed) Common Property Resources: $\quad$ Ecology and Community Based Sustainable Development. Belhaven Press, London

Bromley, D. (ed) 1992. Making the Commons Work: Theory, Practice and Policy. ICS Press, San Francisco.

Bromley, D. W. and Cernea, M. M. 1989. The Management of Common Property Natural Resources: Some Common Conceptual and Operational Fallacies. World Bank Discussion Paper No. 57, The World Bank, Washington DC.

Ciriacy-Wantrup, S. V. and Bishop, R. C. 1975. Common Property as a Concept in Natural Resource Policy. Natural Resources Journal 5(4):713-727.

Cox, Susan, J. B. 1989. Multi-Jurisdictal Resources: MultiTesting a Typology for Problem Structuring. In Berkes, F. (ed.) Common Property Resources: Ecology and Community Based Sustainable Development. Belhaven Press, London. 


\section{Acharya}

Fenny, D., Berkes, F., McCay, B. J. and Acheson, J.

M. 1990. The tragedy of the commons: Twenty-two years later. Human Ecology, 18(1):

$1-9$.

Fisher, R. J. 1991. Studying Indigenous Forest Management Systems in Nepal: Towards more systematic response. Environment and Policy Institute, Working Paper No. 30. EastWest Centre, Honolulu.

Gibbs, C. and Bromley, D. W. 1989. Institutional arrangements for management of rural resources: common property regimes. In Berkes, F. (ed) Common Property Resources: Ecology and Community Based Sustainable Development. Belhaven Press, London

Hardin, G. 1968. The Tragedy of the Commons. Science, 162:1243-1248.

FIMG 1995 a. Forest Act 2049 (1993) and Forest Regulations, 2051 (1995), (Official

Translation). Ministry of Forests and Soil Conservation, Forestry Development Projects, Kathmandu.

HMG 1995 b. Operational Guidelines of the Community Forestry Programme. CPFD/HMG/FDP/USAID, Kathmandu.

Hobley, M. 1996. Participatory Forestry: The Process of Change in India and Nepal. Rural Development Forestry Study Guide 3. ODI, London

Jackson, W. J. and Ingles, A. W. 1995. Developing Rural Communities and Conserving the Biodiversity of Nepal's Forests through
Banko Janakari, Vol. 9, No. 2

Community Forestry. In Proceedings of a Seminar on Community Development and Conservation of Forest Biodiversity through Community Forestry, October 26-28, 1994. RECOFTC Report No. 12, Bangkok.

Jodha, N. S. 1989. Common Property Resources: A Missing Dimension of Development Strategies. World Bank Discussion Series No. 169. The World Bank, Washington DC.

Karki, M., Karki, J. B. S. and Karki, N. 1994. Sustainable Management of Common Forest Resources: An Evaluation of Selected Forest User Groups in Western Nepal. ICIMOD, Kathmandu.

McKean, M. and Ostrom, E. 1995. Common property regimes in the forest: Just a relic from the past? Unasylva, 180(46):3-15.

Ostrom, E., Gardner, R. and Walker, J. (eds) 1994 Rules, Games and Common-Pool

Resources. The University of Michig

Press.

Ostrom, E. 1992. Crafting Institutions for Self- Governing Irrigation Systems. ICS press, San Francisco.

Tiwari, S. 1996. Community Forestry in Nepal: A Property Rights Approach. M. Sc. Dissertation. University of Edinburgh.

Wiersum, K. F. 1989. Forestry and Development: An Overview. Netherlands Review of Development Studies, 2:7-16. 